\title{
DERLEME/REVIEW
}

\section{Obezite ve Ghrelin/Leptin İlişkisi}

\author{
The Interaction of Obesity and Ghrelin/Leptin
}

\author{
Aliye Sağkan Öztürk ${ }^{1 *}$, Abdullah Arpacı ${ }^{2}$
}

${ }^{1}$ Mustafa Kemal Üniversitesi Sağlık Bilimleri Enstitüsü, Moleküler Biyokimya ve Genetik Anabilim Dalı

${ }^{2}$ Mustafa Kemal Üniversitesi Tıp Fakültesi, Tıbbi Biyokimya Anabilim Dalı

\section{ÖZET}

Gelişen dünyanın en önemli sağlık sorunlarından olan obezitenin insidansı son yıllarda hem yetişkinlerde hem de çocuklarda dramatik şekilde artış göstermektedir. Obezite genellikle kısıtı hareket etme ve alınan/harcanan enerji arasındaki dengesizlik sonucunda meydana gelmekte ve pek çok metabolik hastalığın oluşumuna zemin hazırlamaktadır. Hipertansiyon, insülin rezistansı, yüksek trigliserid ve düşük HDL konsantrasyonları ile birlikte obezite metabolik sendromun bir parçasıdır.

Hipotalamus, periferal organlardaki polipeptit hormonlar tarafından alınan sinyaller ile açılı ve tokluğun yönetildiği beyin bölgesidir. Memelilerde oreksijen yani iştah artırıcı olarak tanımlanan periferal peptit ghrelin hormonudur. Ghrelin midenin fundus bölgesinden üretilerek dolaşıma salınır. Büyüme hormonunu stimüle eden reseptörlere bağlanır ve hipotalamusta arkuat nükleustaki nöropeptit $Y$ (NPY) ve aguti ilişkili peptit (AgRP) ifadelerini artırarak gıda alımını uyarır. Ghrelin'le antagonist etki gösteren ve adipoz dokudan ifade edilen leptin ise AgRP ve NPY etkisini inhibe ederken, hipotalamusta bulunan pro-opiomelanokortin (POMC), kokain ve amfetamin ile düzenlenen transkriptinin (CART) aktive edilmesi yoluyla iştahı baskılar. Obezitenin patogenezinde yer alan bu hormonların reseptör ya da genlerinde meydana gelen mutasyonlar ve alınan gıdanın niteliği obezitenin önemli nedenlerindendir.

Yapılan bu derlemenin amacı, güncel çalışmalar ışığında obezite ve hipotalamusta açlık/tokluk sinyallerini uyaran ghrelin ve leptin hormonlarının ilişkisi üzerinde durmak ve bu hormonların agonist ya da antagonistlerinin kullanımının bir tedavi seçeneği olup olmayacağına da bir yaklaşım sunmaktadır.

Anahtar kelimeler: Obezite, Ghrelin, Leptin

\section{ABSTRACT}

The incidence of obesity, the most important health problem in the developing world, has increased dramatically both adults and children in recent years. Obesity usually occurs with limited actions and unbalanced received/spent energy. Obesity is the basis for the formation of many metabolic diseases and a component of metabolic syndrome accompanied by hypertension, insulin resistance, high triglyceride and low HDL concentrations. The hypothalamus is the brain region in which hunger and satiety are managed by signals of the peripheral polypeptite hormones the release from peripheral organs. In mammals, the peripheral peptite identified as oreksigen and an appetite enhancer is the ghrelin hormone. Ghrelin is produced by the fundus region cells and released in the circulation. It binds to growth hormone stimulating receptors and induces food intake through the arcuate nucleus neuropeptite Y (NPY) and arguate-associated peptite (AgRP) in the hypothalamus. Leptin, which is antagonist to ghrelin and expressed by adipose tissue, inhibits AgRP and NPY activity while activating proopiomelanocortin (POMC) and cocaine and amphetamineregulated transcript (CART) in the hypothalamus and suppressing appetite. The quality of the food and the mutations in receptors or genes of these hormones are significantly caused for the pathogenesis of obesity.

The aim of this review, in the light of current studies, is to focus on the obesity and relationship between ghrelin and leptin hormones stimulating of hunger / satiety signals in the hypothalamus and provide an approach to the use of agonists or antagonists of these hormones as a treatment option.

Key words: Obesity, Ghrelin, Leptin

Gönderme tarihi / Received: 14.07.2017 Kabul tarihi / Accepted: 22.05.2018

İletişim: Doç. Dr. Aliye Sağkan Öztürk

Mustafa Kemal Üniversitesi Sağlık Bilimleri Enstitüsü, Moleküler Biyokimya ve Genetik Anabilim Dalı, Antakya/Hatay

Tel: 05357769942 E-posta: alsavet@gmail.com 


\section{Giriş}

Obezite, gelişen dünyanın önemli sağlık sorunlarından biri olup ve morbidite/mortalite oranlarındaki artışın önemli bir nedenidir. Özellikle gıda alımı ve enerji harcaması arasındaki dengesizlikler nedeniyle gelişen obezite epidemik bir hale gelmiştir. Klinik görünüm açısından obezitenin aksine kaşeksi veya patolojik kilo kaybı da kronik hastalığı olan bireyler için önemli bir sorundur. Büyük farklılıklara rağmen her iki tablo da iştahı düzenleyen hormonlarla ilgili pek çok süreci kapsar. Bu hormonlar beyindeki açlık ve tokluk duygularını kontrol eden belirli merkezlerde etkindir. Bu hormonlardaki ya da bunların reseptöründeki mutasyonlar, obezite ya da anoreksiye yol açan önemli patolojilere neden olabilir. Genetik mutasyona sahip bireylerin tanımlanması da sonuç olarak altta yatan nedeni ve hastalık sürecini hedefleyen daha uygun tedavi seçeneklerinin değerlendirilmesini sağlayacaktır. (1).

Obezite vücuttaki bölgesel yağ birikimidir ve çeşitli çevresel koşullardan etkilenebilir. Dünya sağlık örgütünün verilerine göre obezite insanlarda vücut kitle indeksine (BMI) göre değerlendirilmekte ve $\mathrm{BMI}>25 \mathrm{~kg} / \mathrm{m}^{2}$ olması durumunda aşırı kilolu, BMl $>30 \mathrm{~kg} / \mathrm{m}^{2}$ olduğu durumlarda ise klinik tablo obez olarak tanımlanmaktadır (2).

Obezitenin gelişimi için genetik yatkınlık ve obesojenik çevresel koşullarının (uzun süreli hareketsiz çalışma koşulları, fast-food türü beslenmenin yaygınlığı gibi) uygun olması sinerjistik bir etkileşim içerisindedir. Buna rağmen çevresel koşulların obezitenin aleyhine olması genetik yatkınlığın varlığı halinde kilo artışının devamını engellemez (3). Genetik obezite içerdiği genlere bağlı olarak dört şekilde görülmektedir. Bunlardan ilki monojen obezite olup endokrin bozukluklarla ilişkili nadir görülen; fakat erken başlangıçlı ve şiddetli obezite olarak tanımlanmaktadır. Etiyolojisinde, gıda alımı regülasyonunda görevli leptin-melanokortin ekse- nindeki genlerin mutasyonları yer alır. İkincisi, melanokortin 4 reseptör bağlantılı obezitedir. Yetişkinlerde ve çocuklarda obezitenin \%23'ünü oluşturur. Obezite değişken şiddette ve ilave fenotipik özellik bulunmaksızın yalnızca aşırı kilo ile karakterizedir. Üçüncüsü, başka genetik sendromlarla bağlantılı olarak ortaya çıkan sendromik obezitedir. Hastalar klinik olarak obezdir ve zekâ geriliği, dismorfik özellikler ve organa spesifik gelişimsel anormalliklerle ayırt edilirler. Sonuncusu ise polimerik obezitedir ve daha yaygın bir klinik durumdur. Bütün hassas genler kümülatif olarak katkı sağlar ve "obezojenik yaşam tarzı" varlığında anlamlı hale gelir $(4,5)$.

Özellikle gelişmiş ülkelerde obezitenin prevalansının 1980'lerden beri üç kat arttığı görülmektedir. Bu sebeple birçok çalışma obezite ile kardiyovasküler hastalıklar, tip-2 diyabet, uyku apnesi, obezite ile ilişkili kanserler, osteoartrit, psikososyal ve sosyal bozukluklar ve depresyon gibi diğer sağlık sorunları arasındaki ilişkiyi araştırmış ve bu hastalıklar için obezitenin bir risk faktörü olduğunu ortaya koymuşlardır $(6,7)$.

Obezitenin çocuklarda da yaygınlığı son on yılda artış göstermektedir (8). Özellikle yaşamın ilk haftalarında ve aylarında fazla kilo alımı, çocukluk çağında obezite gelişimi için bir risk faktörüdür (9). Yine hayvan modellerinde yapılan çalışmalar da doğum sonrası hızı ıilo alımının obezite ve metabolik düzensizlik riskini artırdığını ortaya koymuştur $(10,11)$.

Hipotalamus, periferal organlardan aldığı sinyaller tarafından beslenme davranışlarının düzenlenmesi ve gıda alımının kontrolünde anahtar rol oynayan beyin bölgesidir. Hipotalamusa bu fonksiyonunda beyin sapı ve ödül ile ilişkili limbik sistem de katkıda bulunmaktadır. Adiposit kökenli hormon olan leptin ve pankreatik $\beta$ hücresinden köken alan insülin, hipotalamusa adipositler hakkında bilgi verir. Kolesistokinin, peptit $Y Y$, pankreatik polipeptit, glukagon benzeri peptit 1 ve oksintomodulin gibi periferal peptitler 
doyma sinyallerini beyine taşırken ghrelin ise açlık sinyallerini iletir (12).

\section{HIPOTALAMUS AÇLIK VE TOKLUK SINYALLERI}

Aksonal projeksiyonlarla birbirine bağlı, anatomik olarak farklı çekirdeklerden oluşan hipotalamus, enerji dengesini düzenlemek için merkezi ve çevresel bilgileri birleştirir. Enerji metabolizmasının düzenlenmesinde hipotalamustaki arkuat nükleus (ARC), ventromedial $(\mathrm{VMH})$, dorsomedial $(\mathrm{DMH})$, paraventriküler $(\mathrm{PVH})$ ve lateral hipotalamik bölge (LHA) önemli rol oynar (13).

Hipotalamusta, arkuat nükleus veya insanlarda infundibular çekirdek kendi nöronları ile etkileşen periferik peptitlerin (ghrelin, leptin, peptit YY) kan-beyin bariyerini aşmasına ve sinyal iletmesine izin verir. Bunlar, gıda alımını azaltan ve kilo kaybını arttıran "pro-opiomelanokortin (POMC)" ve "kokain ve amfetamin ile düzenlenen transkriptin"in (CART) yanı sıra gıda alımı ve kilo kazanımını artıran aguti ilişkili peptit (AgRP) ve özellikle de nöropeptit Y (NPY) nöronlarını içerir (Şekil 1). Bu nöronlar ve peptitler açlık ve tokluk duygularını ve sonuç olarak kilo alımı ve kilo kaybını kontrol ederler (1).

Hipotalamus POMC ve CART'ın üretimi vasıtasıyla tokluğun da ana regülatörü olarak görev yapar. POMC geni hipotalamusun arkuat nükleusu ve hipofiz bezi ile deri ve bağışıklık sistemi gibi pek çok dokuda ifade edilmektedir. POMC, dokuya özgü posttranslasyona uğrar ve oluşan ürün bu dokuda ifade edilen endoproteazlara bağlı kalır. Örneğin; anterior hipofiz bezinde POMC, öncelikle prohormon dönüştürücü 1 enzimi ile adrenokortikotropine (ACTH) dönüştürülür. Primatlar haricindeki memelilerde, ara hipofizde prohormon dönüştürücü 2 , deri/ten renginin kontrolünde rol alan $\alpha$-melanosit uyarıcı hormonu ( $\alpha-M S H)$ üretmek için ACTH'yi parçalara ayırır (Şekil 2). İnsanlardaki hipotalamusla ilgili olarak leptinin (adipoz doku tarafın- dan üretilen bir peptit), ARC'deki POMC'nin $\alpha$ MSH'ye dönüşümünü uyardığı düşünülmektedir (Şekil 1). a-MSH, G protein kenetli reseptörlerine bağlanıp cAMP seviyesini artırmak vasıtası ile beyinde paraventriküler çekirdekte ve diğer pek çok yerde iştah kontrolünde ve enerji homeostazında anahtar rol oynayan melanokortin4 reseptörünün (MC4R) ifadesini artırır. Rodentlerde $\alpha-M S H ' n i n$ intraserebroventriküler uygulaması beslenmeyi engeller ve vücut ağırlığını azaltır. Daha önce belirtildiği gibi, AgRP, MC4R'nin bir antagonistidir. $\mathrm{Bu}$ nedenle, AgRP'nin aşırı ifade edilmesi veya MC4R hasarlı fareler hiperfajik ve obez olup a-MSH'ye karşı duyarlı değildir (14). MC4R mutasyonları, çocukluk döneminden başlayan şiddetli obezitesi bulunan erişkinlerin \%5.8 'inde vardır (15).

Tokluk düzenleyicisi olan POMC genindeki fonksiyon kaybı sonucunda POMC türevi peptitler $(\mathrm{ACTH}, \alpha, \beta$ ve $\mathrm{y}-\mathrm{MSH})$ ifade edilemez. Böylece vücut ağırlığının düzenlenmesinde hipotalamik leptin-melanokortin yolağında ifade edilen a-MSH'nin MC3R ve MC4R'ye bağlanma eksikliği nedeniyle obezite gelişir. ACTH'nin adrenal bezdeki MC2R'ye bağlanmaması hipokortizolizm nedenlerindendir ve POMC türevi peptitlerin ciltte MC1R'ye bağlanmaması da pigment değişikliğine neden olmaktadır (Şekil 2). Bu sendrom, erken başlangıçlı şiddetli obezite, adrenal yetmezlik ve kızıl renkli saçlar ile tanımlanır (16). Kanser ve renal yetmezlik modellerinde MC4R reseptör antagonistleri (BL6020/979, SNT207707, SNT207858) iştahın artırılması, bazal enerji tüketimi ve aşırı kilo kaybı sonucu oluşan kaşeksi semptomlarının belirtilerini hafifletir (17-19). Bu nedenle MC4R antagonistleri kaşeksi için yararlı bir klinik tedavi olabilir iken agonistlerinin geliştirilmesi obezite tedavisi için kullanım alanı bulabilir (20). 


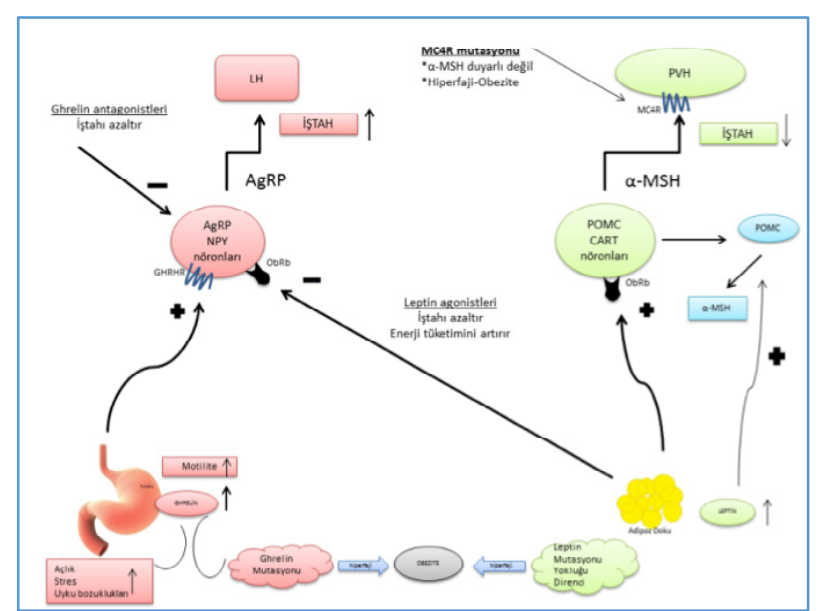

Şekil 1. Hipotalamus ve arkuat nükleusta iştahın leptin ve ghrelin hormonları ile düzenlenmesi ve obezite. LH: Lateral Hipotalamus, PVN: Paraventricular hypotalamus, AgRP: Agouti-related peptite, NPY: Nöropeptit Y, POMC: Pro-opiomelanocortin, CART: cocaine amphetamine related transcript, $\alpha \mathrm{MSH}$ : $\alpha$ Melanocyte-stimulating hormone, ObRb: leptin receptors, GHRHR: The growth-hormone-releasing hormone receptor, MC4R: Melanocortin4 receptor.

Hipotalamustaki bir diğer önemli tokluk regülatörü 102 amino asitli bir prekürsör protein olarak sentezlenen kokain ve amfetamin ile düzenlenen transkript (CART) olup hayvan modellerinde arkuat nöronlarda POMC ile birlikte, insanlarda ise bundan farklı olarak AgRP ve NPY ile birlikte ifade edilmektedir (21). POMC nöronlarına benzer şekilde CART nöronları da doğrudan leptin tarafından uyarılır. CART nöronları endokrin regülasyon, stres ve duyusal değerlendirme, güçlendirme ve mükafat ile ilişkilidir $(22,23)$. Obez farelerde bozulan leptin sinyalleri ile birlikte arkuat nükleusta neredeyse ortadan kalkan CART mRNA ifadesi periferal leptin uygulamaları ile artırılır. CART 82-103 antikorunun intraserebroventriküler enjeksiyonu ile de normal sıçanlarda gıda alımı artmakta, bunun aksine endojen CART peptitleri ile beslenme baskılanmaktadır. Bu çalışmalar CART peptitlerinin beyin tarafından beslenme üzerine etkisinin gıda alımının endojen bir inhibitörü olduğunu göstermektedir $(23,24)$.

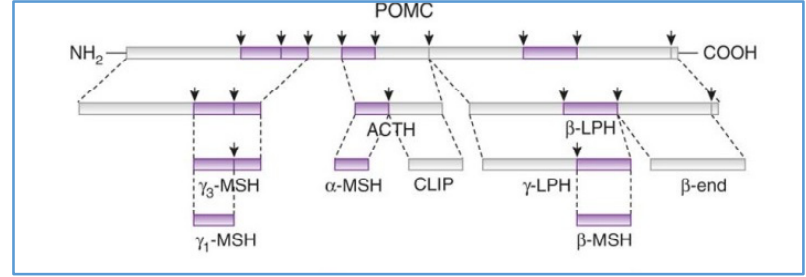

Şekil 2. Pro-opiomelanocortin $\alpha-, \quad \beta$ - ve $\gamma$-melanositstimüle eden hormon $(\mathrm{MSH})$ ve adrenocorticotropin (ACTH)'nin dâhil olduğu bazı biyolojik aktif peptitleri üretmek için post-translasyonel olarak işlenir. Melanokortin peptitleri etkilerini MC1R-MC5R isimli 5 reseotör aracılığı ile gerçekleştirirler (113).

\section{IŞTAHIN ARTIRILMASINDA GÖREVLI PERIFERAL PEPTIT GHRELIN}

Dolaşımdaki peptitler, iştah davranışlarında önemli rol oynamaktadır. En iyi bilinen oreksijen (iştah uyarıcı) periferal peptit olan ghrelin'in beyindeki hedefi büyüme hormonu salgılatıcı hormondur (GHRH). Çoğunlukla midenin fundus mukozasının endokrin hücreleri tarafından üretilmesine rağmen ince bağırsak, hipofiz bezi, hipotalamus, pankreas, akciğer, bağışıklık hücreleri, plasenta, yumurtalık, testis ve böbrek gibi diğer dokularda çok daha küçük miktarlarda bulunur. Ghrelin seviyeleri yemekten önce midenin boş olduğu durumlarda yükselir, gıda alımı sonrasında gıdanın niteliğine de bağlı olarak hızla düşer. Bu sebeple, ghrelin'in gıda alımının başlatıcısı olarak birincil bir rolü olduğu öne sürülmüştür (25). Organizmada multifonksiyonel bir peptit olarak görev yaparak sadece iştah değil enerji dengesi, gastrik asit salınımı, insülin sekresyonu, gastrik motilite ve mide/bağırsak mukozasının işlevsel olarak düzenlenmesinde de rol oynar (26-29).

Ghrelin'in aktif formu 28-amino asitlidir. Ancak 117 aminoasitli preproghrelin olarak sentezlendikten sonra posttransisyonel işlemlerle aktif forma dönüşür. Aktif hormonun üçüncü pozisyonundaki serine n-oktanoil eklenir ve ghrelin'e GH salgılatıcı özelliğini kazandırır. Ghrelin ilk defa Kojima ve ark. (30) tarafından sıçanların ve insanların midelerinde tespit edilmiştir. Mide, 
plazmadaki ghrelin'in ana kaynağıdır ve dolaşımdaki ghrelin'in yaklaşık \%70'i midenin mukozal tabakasındaki hücreler tarafından üretilmektedir (31).

Ghrelin reseptörü, G-proteinine bağlı reseptör olan GH sekretör reseptörü tip 1a (GHSR1a)'dır. Bu reseptör merkezi sinir sisteminde iştah ve enerji dengesinin düzenlenmesinde, hipotalamik çekirdekler, dorsal vagal kompleks ve mezolimbik dopaminerjik sistemde bulunur. Ghrelin, GH, ACTH, kortizol, aldosteron, katekolamin ve prolaktin sekresyonunun uyarılması da dâhil pek çok fizyolojik süreçte görevlidir. Ekzojen ghrelin uygulamasının glukoz homeostazını, gastrointestinal sistem motilitesini, pankreas ekzokrin salgılanmasını, kardiyovasküler fonksiyonu, bağışıklığı ve yangıyı etkilediği ortaya konulmuştur (32). Fakat metabolik sendrom (kanser için bir risk faktörü) gibi obezite ile ilişkili patolojiler için ortak genom incelemesi, gen ifadesi verileri, endokrin ve bağışıklık sistemleri ile ghrelin ekseni arasındaki bağlantı henüz tam olarak aydınlatılamamıştır (33).

Rat midesinde asit salgılayan hücrelerin submukozasına yerleştirilen mikrodiyaliz probları ile uygulanan epinefrin, norepinefrin, endotelin ve sekretin hormonları ghrelin sekresyonunu artırırken somatostatin ve gastrin salgılatıcı peptit ise inhibe etmektedir (34). Yemek sonrası ghrelin'deki düşüşün mekanizması tam olarak açıklanamamasına rağmen duodenum ve jejunumu besin maddesine maruz burakılan sıçanlarda diyetteki glikoz, lipidler ve amino asitlerin ghrelin seviyelerini inhibe ettiği ortaya konulmuştur. Ghrelin'in glikoz veya amino asit içeren besinler alındığında lipitlere oranla zayıf şekilde baskılanması yüksek yağı diyetle kilo artışı sağlayan mekanizmayı açıklayabilir (35).

G proteine kenetli reseptör ile işlev gören ghrelin'in aynı moleküler farmakolojik özelliklere sahip iki doğal reseptör mutasyonu (Ala204Glu'da ve Phe279Leu) belirlenmiş ve bu mutasyonlar hem kısa boylu gelişme fenotipi hem de ergenlik dönemi obezitesi ile ilişkilendirilmiştir $(36,37)$. Ukkola ve ark. (38) ghrelin genindeki düşük frekanslı dizi varyasyonunun obezitenin etiyolojisinde rol oynayabileceğini ifade etmişlerdir.

Ghrelin'in oreksijenik; yani iştah artırıcı aktivasyonu hipotalamusta spesifik reseptörlerini barındıran nöronlar ile düzenlenmektedir ve ghrelin, metabolizmanın çok yönlü bir düzenleyicisidir (39-41). Ghrelin reseptörleri, gıda alımını ve doygunluğunu düzenleyen hipotalamik nöronlarda yer almasının yanı sıra (42) yeme davranışına katkıda bulunan hipotalamik olmayan beyin bölgelerindeki nöronlarda da bulunur (43). İştahı indükleyerek kısa vadede enerji dengesini düzenler. Uzun vadede ise vücut ağırlığı ve yağlanmanın artmasına neden olur (15).

Rodentlerde ghrelin merkezi ve periferik etkileri yoluyla besin alımını, vücut ağırlığı artışını ve yağlanmayı artırır $(40,44)$. Ghrelin'in oreksijenik etkisi beyindeki NPY / AgRP aracılığıyladır (45). Fakat normal diyetle beslenen farelerde ghrelin'in gıda alımı için NPY / AgRP'ye bağımlıığı sınırlıdır. Ratlar lezzetli bir diyetle karşılaştığında bu nöronların etkileri yoktur (46). NPY, kardiyovasküler kontrol, kaygı, cinsel davranış ve beslenme gibi birçok fizyolojik fonksiyona karışmakta (47) ve özellikle memeli beyninde en kuvvetli oreksijenik peptit olarak kabul edilmektedir (48). Sadece memelilerde değil balıklarda da hem NPY hem ghrelin besin alımını ve hipofiz bezinden büyüme hormonu salınmasını uyarmaktadır $(49,50)$. Babaei ve ark. (51) yaptıkları çalışmada diyetteki makro besin kompozisyonunun bazı balık türlerinde oreksijenik ve anoreksijenik peptitlerin gen ifadesini düzenlediğini belirtmişlerdir. Ayrıca besin içeriği iştahı düzenleyen peptitleri de (özellikle CCK ve ghrelin) modüle etmektedir.

Mide motilitesinin düzenlenmesinde görevli olan ghrelin düzeyleri açlıkta yükselirken mide kontraksiyonları özellikle mide boş olduğunda sıklaşmaktadır. Fakat yediğimiz gıdalar bağırsakla- 
rımıza ulaştığı anda ghrelin düzeyleri düşer. Bu sebeple seçilen gıdaların niteliği ve egzersiz ghrelin/leptinde değişimlere neden olur. Ayrıca yetersiz ve düzensiz uyku gibi sebepler ile enerji homeostazında meydana gelen değişiklikler merkezi sinir sisteminde glikozun daha fazla harcanmasına sebep olur. Ghrelin seviyeleri buna paralel olarak artar, ghrelin antagonisti leptin seviyeleri ise azalır. Bu durum obezite ile sonuçlanabilir. Ghrelin ile uyarılan ve artırılan NPY gen ifadeleri, leptin ile indüklenen gıda alımındaki azalmayı ortadan kaldırmaktadır. Aksine NPY ifadelerinin engellenmesi leptinin aracılık ettiği gıda alımının baskılanmasına neden olur ve bunun ana mekanizmasıdır (40).

Alınan gıdanın niteliği ve periferal peptitler birbirleriyle ilişkilidir. D vitamini takviyeli yoğurt tüketimi dolaşımdaki leptin ve ghrelin'de bir artışa neden olarak iştah hormonlarını düzenler ve insülin duyarlıığını iyileştirir (52). Obez yetişkinlerde vücut yağ kitlesinin serum $25(\mathrm{OH}) \mathrm{D}$ vitamini konsantrasyonları ile ters orantılı olması (53) muhtemelen yağ dokuda $D$ vitamininin ve metabolitlerinin tutulumundan kaynaklanmaktadır (54). Pek çok çalışma D vitamini yetersizliği olanlara $D$ vitamini takviyesinin obezite dahil çeşitli sağlık sorunlarına faydalı olduğunu göstermiştir $(55,56)$. Yetişkinlerde yapılan epidemiyolojik çalışmalar düşük $D$ vitamini alımlarında insülin direnci ve tip 2 diyabet prevelansının daha yüksek olduğunu belirlemişlerdir (57).

Obez bireylerde beslenme periyodunda dolaşımdaki ghrelin miktarı düşüktür. Oreksijenik ve metabolik etkilerinden dolayı ghrelin kardiyak ve renal hastalıklar, kanser kaşeksisi, yaşa bağlı zayıflık gibi katabolik koşullarda kilo kaybı ve protein parçalanmasını antagonize ederek potansiyel olarak fayda sağlayabilir. Teorik olarak ghrelin reseptör antagonistleri oreksijenik sinyalleri bloke ederek anti-obezite ilaçları olarak çalışabilir ve obezitenin tedavisinde faydalı olabilir (58). Ancak bu etki canlının BMl'ne göre değişebilir ve ghrelin uygulamaları zayıf kon- düsyonlu canlılarda gıda alımını baskılayabilir (59).

Obezitenin tedavisi için kullanılan amfetamin (AMPH), iştahın bastırılmasında obez bireylerde kullanım alanı bulmuştur. Sıçanlarda AMPH tedavisi ile ilgili yapılan bir çalışmada, bu tedavinin periferik ve merkezi ghrelin sisteminin NPY/POMC aracılı iştah kontrolünün düzenlenmesine katkıda bulunarak etkili olduğunu göstermiştir (60). Hipotalamik PI3K ve STAT3 sinyal yolakları amfetaminin NPY/POMC aracılı iştah kontrolünün düzenlenmesinden sorumludur ve bu düzenlenmenin moleküler temelini oluşturur (61).

Ghrelin'in sıçanlarda intraserebroventriküler olarak uygulanması gıda alımı ile kilo alımında artış ve yağlanmaya yol açar (62). Benzer şekilde, ghrelin'in obez ve zayıf insanlara uygulanması besin alımının artmasına sebep olmaktadır (63). Arkuat çekirdekte NPY ve AgRP üretimini uyararak besin alımı/vücut ağırlığında artışa neden olan ghrelin (64) adipogenezin teşviği, apopitozun inhibisyonu, enerji tüketimi için yağ asidi oksidasyonundan glikolize değişim/geçiş ve sempatik sinir sistemi aktivitesinde inhibisyon ile enerji dengesini değiştirir $(44,65$, 66).

Yaşamın erken dönemlerindeki aşırı kilo beyinde iştahının düzenlenmesinde görevli kritik metabolik faktörlerin değişimlerinden kaynaklanan erişkin yaş obezitesi için önemli bir risk faktörüdür. Erkek sıçanlarda erken yaştaki aşırı beslenmenin aşırı vücut ağırlığına neden olduğu; fakat bu artışın yetişkin yaş döneminde kısmen hafifletilebileceği ifade edilmiştir (67).

Yüksek yoğunluklu egzersiz yetişkinlerde iştahı bastırır ve bunun iştahı düzenleyen hormonların aracılığıyla olduğu düşünülmektedir. Yüksek yoğunluklu egzersizin hem normal kilolu hem de aşırı kilolu/obez erkek çocuklarda (10-18 yaş) meydana getirdiği IL-6 artışı iştahtaki azalma ile ilişkilendirilmiş ve yine iştahın bastı- 
rılmasında az dahi olsa aktif ghrelin'in azalması ve/veya endojen kortizolün artmasının da etkili olabileceği ifade edilmiştir. Aksine leptin ve diğer bazı polipeptit hormonlar (glukagon-like peptit 1, peptit $Y Y$ ) yüksek yoğunluklu egzersizden etkilenmemiş ve iştah ile ilişkilendirilememiştir (68).

Yüksek yoğunluklu egzersiz sonucunda kaslardan üretilen ve kandaki düzeyi artan IL-6 iştahın bastırılmasının olası bir nedenidir. IL-6 kas proteini biyosentezinin (69), termoregülasyonun (70), enerji harcamalarının (71) ve vücut ağırığının düzenlenmesinin (72) bir aracısıdır. Diğer bir enflamatuar mediatör olan IL-1 $\beta$, ghrelin üreten hücre hattında (MGN3-1), ghrelin mRNA ekspresyonunu doğrudan baskılamıştır ve bu nedenle IL-1 $\beta$ 'nın enflamatuar süreçlerde ghrelin ekspresyonunun önemli bir düzenleyicisi olduğu ifade edilmiştir (73).

Ghrelinerjik sistem sadece iştahın homeostatik düzenlenmesi ve besin alımında görevli değildir (74). Stresin ardından meydana gelen yükselmiş ghrelin plazma seviyeleri, stresle indüklenen depresyon ve kaygı da dâhil stresin sonuçlarına karşı savunmada ve bunların önlenmesinde potansiyel bir rol oynayabilir (75). Kan ghrelin seviyelerinde stres sonrasında yükselme ghrelin'in kronik yönden önemini ortaya koymuştur. Hem diyet hem de stresin katkıda bulunduğu anksiyete ve depresyonla ilişkili bozukluklara yönelik beyin-bağırsak ekseninde yer alan ghrelinerjik sistemin gelecekte terapötik olarak umut verici bir aday olabileceği düşünülmektedir. Ghrelin'de stres kaynaklı yükselmeler, kronik stres ya da atipik depresyon sonrasında artan obezite prevalansına muhtemelen katkıda bulunan bir faktördür (74). Obez kadınlarda yapılan bir çalışmanın sonucunda diğer faktörler standardize edildikten sonra, plazma ghrelin düzeylerinin yaşam kalitesinin (quality of life/QOL) bir göstergesi alabileceği ve ghrelin seviyelerinin obez kadın hastalarda izlenmesi gereken bir belirteç olduğu ortaya konulmuştur.
$\mathrm{Bu}$ durum ghrelin'in stres ve metabolik sendromla ilişkisine bağlanmaktadır (76).

Ghrelin, ödül sistemlerinin modülasyonu (77, $78)$ ve öğrenme ve bellek performansı $(79,80)$ gibi çeşitli biyolojik fonksiyonlara da katılarak dejeneratif hastalıklara karşı koruyucu bir rol oynamaktadır (81). Bu etkiler esasen ghrelin'e cevap veren nöronlar aracılığıyla olsa da astrositler gibi glial hücreler de bu süreçlere katılabilir. Merkezi sinir sisteminin destek dokusunu oluşturan glia hücrelerinden olan astrositler hipotalamusta metabolik hormonlar ve besinler ile enerji homeostazisinin kontrolü de dâhil bazı metabolik döngülere katıır. Ghrelin, glikoz taşınımı ve metabolizması, sitokin ve trofik faktör üretimi gibi astrosit fonksiyonlarını düzenlemektir. Bununla birlikte bu hormonun glial hücrelere etkilerinin tümü ve hipotalamustaki oreksijenik etkilere nasıl aracılık ettiği tam olarak açık değildir. Ghrelin'in beyin astrositlerindeki glikoz taşınımı ve metabolizmasına etkileri ve bu etkilerin hipotalamusla sınırlı kalıp kalmadığı da henüz açıklanamamıştır. Ghrelin'in astrositlere etkileri ve astrositlerin iştah kontrolündeki rolünün açıklanabilmesi için yeni çalışmalara intiyaç duyulmaktadır (82).

\section{IŞTAHIN AZALTILMASINDA GHRELIN ANTAGONISTI PERIFERAL PEPTIT LEPTIN}

Açlığa neden olduğu en iyi bilinen periferal peptit olan ghrelin'in aksine tokluk ile ilişkili bilinen birçok periferal peptit hormon vardır. Bu hormonlar gastrointestinal sistem, pankreas ve yağ dokusu da dâhil çeşitli organlardan salgılanırlar. $\mathrm{Bu}$ hormonlardan bazıları kolesistokinin, peptit YY, pankreatik polipeptit, oksintomodulin, glukagon benzeri peptit-1, gastrik inhibitör peptit, insülin, leptin ve adiponektindir. Bu periferal peptitlerden en önemlisi ve beyinde en etkili olanı yağ dokudan sentezlenen ve adipokinlerden olan leptindir (1).

Yağ dokusu, canlı vücudunda pek çok hormonu dinamik olarak salgılayarak anahtar fizyolojik 
süreçleri düzer. Adipokinler olarak adlandırılan leptin, adiponektin, resistin gibi hormonların salgılandığı diffüz endokrin bir organdır. Bununla birlikte, adipokinler ve reseptörleri, hipofiz bezi dâhil olmak üzere diğer dokularda eksprese edilir ve düzenlenirler. Primatlarda hipofiz bezi, leptin, adiponektin, resistin gibi adipokinleri eksprese ederek bunların işlevini uygun şekilde modüle ve takviye eden bir düzenleyici gibi görev yapmaktadır (83).

Leptin, 7. kromozomun uzun kolunda bulunan (7q31) LEP (OB) geninde kodlanan, 167 aminoasitli protein ürünü olup 16 kilodalton moleküler ağırlıkta ve tek zincirli-polipeptit yapıya sahip önemli iştah düzenleyici bir hormondur. Beyaz ve kahverengi yağ dokusu, mide, plasenta, meme bezi, yumurtalık folikülleri, kalp, kemik/kıkırdak doku, bazı fetal organlar ve beyin tarafından üretilir. OB geni tüm yağ dokularda eksprese edilmesine rağmen subkutan yağ dokusunda ve omentum yağında bu oran daha yüksektir. Leptin düzeyleri, vücut yağ kitlesi ile pozitif yönde ilişkilidir. Leptin salgısı gıda içerikleri tarafından çok fazla etkilenmemekte; ancak sirkadiyen ritm ile düzenlenmektedir. Gece yarısından sabahın ilk saatlerine kadar yüksek seviyelerle ve öğlen ile öğleden sonra en düşük düzeyde olup pulsatil şekilde salgılanır $(84,85)$. Beyindeki sinir ve nörohormonal bileşenler leptin sekresyonunu bu şekilde düzenler. Vücut ağırığı homeostazının düzenlenmesinde önemli bir rol oynayan leptin (86) vücutta çeşitli dokular üzerinde ve özellikle beyinde etkilidir (87).

Leptinin yokluğunda veya hafif leptin dalgalanmalarında hipotalamusun arkuat çekirdeği (ARC), hipotalamus paraventriküler çekirdeği (PVN), lateral hipotalamus (LH) ve dorsomedial hipotalamik çekirdeğin nöronal bağlantıları $(\mathrm{DMH})$ baskılanarak metabolik komplikasyonlara ve obeziteye yol açar $(88,89)$. Bu komplikasyonlar, ekzojen leptin uygulamaları ile leptin yoksun yeni doğan farelerde (Lepob/Lepob) ARC projeksiyonlarının gelişimine katkıda bulunur ve leptin, in vitro ARC nöronlarında sinir büyümesini teşvik etmektedir. Fakat yetişkin Lepob/Lepob farelerde ARC'dan gelen sinir projeksiyon yollarının kalıcı olarak bozulduğu durumlarda leptin tedavisi bu nöroanatomik defekti tersine çevirmemektedir. Leptin hipotalamus gelişiminde nörotrofik bir rol oynar. Erişkinlerde leptinin akut gıda alımı düzenlemesindeki etkileri neonatal dönemden başlamakta olup leptin uygulamalarının faydalarının yenidoğanlarda kısa ve kritik bir dönemle sınırlı olduğu düşünülmektedir (90).

Ob gen mutasyonu olan farelerde hem dolaşımdaki leptin yokluğu hem de besin alımının artması ve enerji tüketiminin azalması nedeniyle şiddetli obezite gelişir (91). Leptin uygulaması ile gıda alımı ve enerji tüketimi normalize edilebilir (92). İnsanlarda leptin eksikliği sonucunda meydana gelen obezite, dolaşımdaki CD4(+) T hücrelerinin sayısının azalması, bozulmuş $T$ hücre aracılı bağışık ve sitokin salınımı rekombinant leptin uygulamaları ile düzeltilebilir. Bu uygulama, konjenital leptin eksikliği ile ilişkili birden fazla fenotipik anormallik üzerinde oldukça etkili ve sürekli yararlı etki sağlamıştır (93). Obez popülasyonun yaklaşık \%5'inde nispi leptin eksikliği bulunmaktadır ve bu bireylerin leptin tedavisinden fayda görmesi de olasıdır (94).

Leptin reseptörleri (Ob-Rb), sinyal transdüksiyonunun Janus aktive edici kinaz (JAK) sinyal transdüseri ve transkripsiyon aktivatörü (STAT) yolağını kullanan sitokin reseptör süper ailesine aittir. Bunlar çok sayıda farklı "splicing" varyantlarına sahiptir. Hipotalamusta ARC, PVN, DMH ve LH alanı içeren çok sayıda farklı bölgede ifade edilir (95). Leptin reseptörüne bağlandıktan sonra anorektik peptitleri (POMC ve CART dahil) uyarırken oreksijenik peptitlerin (NPY ve AgRP) inhibisyonuyla sonuçlanan spesifik bir sinyal kaskadını başlatır ve iştah azalır, enerji tüketimi artar $(96,97)$. Buna ek olarak, erken başlangıçlı şiddetli obezitesi bulunan bireylerin \%3'ünde bozulmuş leptin reseptör sinyalini içeren mutasyonlar bulunduğu belirlenmiştir (98). 
Hiperfaji ve enerji tüketiminde azalma ile obeziteye yol açan leptin direncinin nasıl geliştiği ve mekanizması halen tartışma konusudur. Hipotalamusta nöronal enflamasyon hipotalamik leptin direnci için bir mekanizma olarak öne sürülmüştür $(99,100)$. Ayrıca leptin, hasar gören beyin bölgelerinde düşük enflamatuar mediatör konsantrasyonlarına neden olarak hem düşük kilolu hem de obez bireylerde hücre büyümesini uyarıcı etki yaparak kanser ve diğer merkezi sinir sistemi patolojilerinin gelişimini ve malignensiyi de hızlandırabilir (101).

Son yıllarda astrositlerin de hipotalamik leptin sinyalizasyonunu ve reseptörlerini içerebileceği ve bu sinyal yolağına katıldığı ifade edilmektedir (100, 102,103). Kemirgenlerde yüksek yağlı diyet tüketimi, astrositlerin sayısında artış sonucunda oluşan reaktif astrogliozis ve mediobazal hipotalamusta nöron hasarı ile birlikte hızı enflamatuar sinyallere neden olur (103). Bu da leptin sinyalinin bozulması ile ilişkili olup hipotalamik nöronal hasar, enflamasyon ve obeziteye yol açar (104). Bir başka deyişle astrogliozis, leptinin nöronlara erişmesine ve enerji dengesini kontrol etmesine engel oluşturabilir (100).

Fetal gelişme sırasında ve doğumdan sonraki ilk yaşlarda yüksek yağlı diyetle beslenme, leptin, insülin ve ghrelin gibi hormon düzeylerinde değişikliğe neden olur $(105,106)$. Doğum öncesi gebelik haftasına göre kilo alımı ve 1, 2 ve 3 . trimesterlerde alınan kordon kanı (erken neonatal dönem) serum leptin düzeyleri, fetal çevrenin ve beslenmenin daha sonraki yaşamda ortaya çıkabilecek sağlık sorunlarının değerlendirilmesinde kullanımı faydalıdır. Bu hormonlar ayrıca büyüme, metabolizma ve bağışıklık sistemi ile bağlantılı sinyal yolaklarında görev alarak fetal büyüme ve hastalık arasında olası bir bağlantı kurulmasını sağlayabilir (107).

Doğum sonrası erken yaşlardaki insülin ve ghrelin gibi hormonlarda meydana gelen değişim leptinin enerji homeostazının düzenlenmesi için gerekli olan hipotalamik nöronal formasyo- nunu bozma potansiyeline sahiptir $(90,108)$. Obezite ve tip 2 diyabet predispozisyonu da ortaya çıkabilir (109-111).

Maternal ve postnatal dönem beslenme hataları enerji homeostazında bozulmalara neden olmaktadır. Çikolata ve yüksek sükrozlu içecek kullanılarak hipotalamik leptin sinyalleri ve astrosit morfolojilerinin değerlendirildiği bir çalışmada gebelikte çikolata ve sükrozlu içecek tüketen sıçanlardan doğan ve emzirme döneminde de yine aynı diyete maruz kalan sıçan yavrularında uzun süreli fenotipik değişiklikler meydana gelmiştir. Yine bu yavrularda postnatal dönemde daha düşük enerji alımına rağmen ARC'de açlık pSTAT3 aktivitesinde azalma, leptin sinyallerinde bozulma ve enerji dengesinde değişikliğe bağlı obezite gelişmiştir (112).

\section{SONUÇ}

Sonuç olarak dünyada yaygın kronik bir sağlık sorunu haline gelen ve pediatrik bir problem olarak da günümüzde yaygınlaşan obezitenin açıklanmasında açlık ve toklukla ilişkili polipeptit hormonlardan olan leptin ve ghrelin'in değerlendirilmesi önerilmektedir. Hipotalamus merkezi sinir sisteminde açlık ve tokluğun değerlendirildiği yegâne bölgedir. Açlık ve tokluk sinyalleri hipotalamusta bu hormonlarla ilişkili reseptörlerin uyarılması ya da inhibe edilmesi ile iletilmektedir. Leptin ve ghrelin hormonu ve/veya reseptörlerinde meydana gelen mutasyonlar (leptin-melanokortin yolağındaki mutasyonlar, leptin reseptör gen mutasyonları, POMC gen mutasyonları, ghrelin reseptör mutasyonları, AgRP gen mutasyonları, MC4R mutasyonu vs) sonucunda da obezite gelişmektedir.

Obezitenin gelişimi çevresel ve genetik pek çok faktörden etkilenmektedir. Gıdanın niteliği ve miktarı ile ghrelin hormonu değişimle- 
ri bu faktörlerden bazılarıdır. Dahası, hamilelikte annenin beslenmesi ve anne karnında kilo artışı ile başlayan obezite süreci doğum sonrası, hatta ilerleyen yaşlarda da metabolik sendrom için bir risk faktörüdür. Özellikle çevresel koşullar, beslenme ve besin içerikleri ile yetersiz egzersiz obeziteyi tetiklemektedir. Obezite sadece metabolik ve endokrin bir hastalık olarak değil, aynı zamanda psikososyal bir problem olarak da kişileri etkilemektedir. Bahsi geçen oreksijen ghrelin ve anoreksijen leptin hormonlarında meydana gelen değişiklikler de depresyon ve stresin oluşumuna katkıda bulunmaktadır. Stres ve depresyon iştahı etkilemekte ve birbirini tetikleyen kısır bir döngü oluşmaktadır.

Obezitenin tedavisinde çeşitli seçenekler mevcut olsa da yaşam süresi ve kalitesinin uzatılması için obezitenin patogenezinin daha iyi anlaşılması gerekmektedir. Bu bağlamda obezite ile birlikte hipotalamus ve leptin/ghrelin ekseni hakkında yeni araştırmalara intiyaç duyulmaktadır.

\section{KAYNAKLAR}

1. Austin J, Marks D. Hormonal Regulators of Appetite. Int J Pediatr Endocrinol 2009; 2009:141753.

2. Wellens RI, Roche AF, Khamis HJ, Jackson AS, Pollock ML, Siervogel RM. Relationships between the Body Mass Index and body composition. Obes Res 1996; 4(1):35-44.

3. Herrera BM, Lindgren CM. The Genetics of Obesity. Curr Diab Rep 2010; 10(6):498-505.

4. Rosenbaum M, Leibel RL. The physiology of body weight regulation: relevance to the etiology of obesity in children. Pediatrics 1998; 101:525-39.

5. O'Rhahilly S. Insights into obesity and insülin resistance from the study of extreme human phenotypes. Eu J

Endocrinol 2002; 147(4):437-41.

6. Dixon JB. The effect of obesity on health outcomes. Molecular and Cellular Endocrinology 2010; 316:104-8.

7. Mokdad AH, Ford ES, Bowman BA, Dietz WH, Vinicor F, Bales VS, et al. Prevalence of obesity, diabetes, and obesity-related health risk factors, 2001. JAMA 2003; 289(1):76-9.

8. Ogden CL, Carroll MD, Kit BK, Flegal KM. Prevalence of childhood and adult obesity in the United States, 2011-2012. Jama 2014; 311:806-14.

9. Taveras EM, Rifas-Shiman SL, Sherry B, Oken E, Haines J, Kleinman K, et al. Crossing growth percentiles in infancy and risk of obesity in childhood. Arch Pediatr Adolesc Med 2011; 165:993-998.

10. Desai M, Jellyman JK, Han G, Beall M, Lane RH, Ross MG. Maternal obesity and high-fat diet program offspring metabolic syndrome. Am J Obstet Gynecol 2014; 211-37.

11. Habbout A, Li N, Rochette L, Vergely C. Postnatal overfeeding in rodents by litter size reduction induces major short- and long-term pathophysiological consequences. J Nutr 2013; 143:553-62.

12. $\mathrm{Yu} \mathrm{JH}$ and Kim MS. Molecular Mechanisms of Appetite. Regulation Diabetes Metab J 2012; 36(6):391-398.

13. Al Massadi O, López M, Tschöp M, Diéguez C, Nogueiras R. Current Understanding of the Hypothalamic Ghrelin Pathways Inducing Appetite and Adiposity. Trends in Neurosciences 2017; 40(3):167-80.

14. Huszar D, Lynch CA, Fairchild-Huntress V, Dunmore JH, Fang Q, Berkemeier LR, et al. Targeted disruption of the melanocortin-4 receptor results in obesity in mice. Cell 1997; 88(1):131-41,

15. Farooqi IS, Keogh JM, Yeo GS, Lank EJ, Cheetham T, O'Rahilly S. Clinical spectrum of obesity and mutations in the melanocortin 4 receptor gene. $\mathrm{N}$ Engl J Med 2003; 348(12):1085-95. 
16. Krude $H$, Biebermann $H$, Schnabel $D$, Tansek MZ, Theunissen P, Mullis $P E$, et al. Obesity due to proopiomelanocortin deficiency: three new cases and treatment trials with thyroid hormone and ACTH4-10. J Clin Endocrinol Metab 2003; 88(10):4633-40.

17. DeBoer MD, Marks DL. Therapy insight: Use of melanocortin antagonists in the treatment of cachexia in chronic disease. Nat Clin Pract Endocrinol Metab 2006; 2(8):459-66.

18. Weyermann $P$, Dallmann $R$, Magyar J, Anklin C, Hufschmid M, Dubach-Powell $J$, et al. Orally available selective melanocortin-4 receptor antagonists stimulate food intake and reduce cancerinduced cachexia in mice. PLoS One 2009;4(3):4774.

19. Dallmann $R$, Weyermann $P$, Anklin C, Boroff M, Bray-French K, Cardel B, et al. The orally active melanocortin-4 receptor antagonist BL-6020/979: a promising candidate for the treatment of cancer cachexia. J Cachexia Sarcopenia Muscle 2011;2(3):163-174.

20. Foster AC, Chen C, Markison S, Marks DL. MC4 receptor antagonists: a potential treatment for cachexia. IDrugs 2005; 8(4):314-9.

21. Menyhért J, Wittmann $\mathrm{G}$, Lechan RM, Keller E, Liposits Z, Fekete C. Cocaine- and amphetamine-regulated transcript (CART) is colocalized with the orexigenic neuropeptite $\mathrm{Y}$ and agoutirelated protein and absent from the anorexigenic alpha-melanocytestimulating hormone neurons in the infundibular nucleus of the human hypothalamus. Endocrinology 2007; 148(9):4276-81.

22. Koylu EO, Couceyro PR, Lambert PD, Kuhar MJ. Cocaine- and amphetamine-regulated transcript peptite immunohistochemical localization in the rat brain. J Comp Neurol 1998; 391(1):115-32.
23. Kristensen $P$, Judge ME, Thim L, Ribel $U$, Christjansen KN, Wulff BS, Clausen $\mathrm{JT}$, et al. Hypothalamic CART is a new anorectic peptite regulated by leptin. Nature 1998; 393(6680):72-6.

24. Lambert PD, Couceyro PR, McGirr KM, Dall Vechia SE, Smith Y, Kuhar MJ. CART peptites in the central control of feeding and interactions with neuropeptite Y. Synapse 1998; 29(4):293-8.

25. Cummings DE, Purnell JQ, Frayo RS, Schmidova K, Wisse BE, Weigle DS. A preprandial rise in plasma ghrelin levels suggests a role in meal initiation in humans. Diabetes 2001; 50(8):1714-9.

26. Sagkan Öztürk $A$, Güzel M, Kontas Askar T, Aytekın I. Evaluation of the hormones responsible for the gastrointestinal motility in cattle with displacement of the abomasum ghrelin motilin and gastrin. Vet $\operatorname{Rec} 2013 ;$ 172(24):636.

27. Sagkan Öztürk A, Kontas Askar T. Sekum Dilatasyonlu ve Omazum Konstipasyonlu Sütçü Sıgırlarda Motilite Hormonlarının Degerlendirilmesi. Kafkas Universitesi Veteriner Fakultesi Dergisi 2015; 21(6):919-22.

28. Sagkan Ozturk A, Demir EA, Ozturk A. Prokinetics stimulate the increase of ghrelin in mice. Bratisl Lek Listy 2016; 117(12):726-29.

29. Lin TC, Hsiao M. Ghrelin and cancer progression. Biochim Biophys Acta 2017; 1868(1):51-7.

30. Kojima M, Hosoda H, Date Y, Nakazato $\mathrm{M}$, Matsuo H, Kangawa K. Ghrelin is a growth-hormone-releasing acylated peptite from stomach. Nature 1999; 402:656-60.

31. Jeon TY, Lee S, Kim HH, Kim YJ, Son $\mathrm{HC}, \mathrm{Kim} \mathrm{DH}$, Sim MS. Changes in plasma ghrelin concentration immediately after gastrectomy in patients with early gastric cancer. J Clin Endocrinol Metab. 2004; 89:5392-6.

32. van der Lely AJ, Tschöp M, Heiman ML, Ghigo E. Biological, physiological, pathophysiological, and pharmacological 
aspects of ghrelin. Endocr Rev 2004; 25(3):426-57.

33. Seim I, Crisp G, Shah ET, Jeffery PL, Chopin LK. Abundant ghrelin gene expression by monocytes: Putative implications for fat accumulation and obesity. Obesity Medicine 2017; 5:1-3.

34. de la Cour CD, Norlen P, Hakanson R. Secretion of ghrelin from rat stomach ghrelin cells in response to local microinfusion of candidate messenger compounds: a microdialysis study. Regul Pept 2007; 143:118-26.

35. Overduin J, Frayo RS, Grill HJ, Kaplan $\mathrm{JM}$, Cummings DE. Role of the duodenum and macronutrient type in ghrelin regulation. Endocrinology 2005; 146:84550.

36. Pantel J, Legendre M, Cabrol S, Hilal L, Hajaji Y, Morisset S, et al. Loss of constitutive activity of the growth hormone secretagogue receptor in familial short stature. J Clin Invest 2006; 116:760-68.

37. Holst B, Schwartz TW. Ghrelin receptor mutations--too little height and too much hunger. J Clin Invest 2006; 116(3):637-41.

38. Ukkola O, Ravussin E, Jacobson $P$, Snyder EE, Chagnon M, Sjöström L, et al. Mutations in the preproghrelin/ghrelin gene associated with obesity in humans. $J$ Clin Endocrinol Metab 2001; 86(8):3996-9.

39. Müller TD, Nogueiras R, Andermann ML, Andrews ZB, Anker SD, Argente J, et al. Ghrelin. Mol Metab 2015; 4:437-60.

40. Nakazato M, Murakami N, Date Y, Kojima $\mathrm{M}$, Matsuo $\mathrm{H}$, Kangawa $\mathrm{K}$, et al. A role for ghrelin in the central regulation of feeding. Nature 2001; 409:194-8.

41. Schmid SM, Hallschmid M, Jauch-Chara $\mathrm{K}$, Born J, Schultes B. A single night of sleep deprivation increases ghrelin levels and feelings of hunger in normal-weight healthy men. J Sleep Res 2008; 17(3):331-4.

42. Dickson SL, Luckman SM. Induction of cfos messenger ribonucleic acid in neuropeptite y and growth hormone $(\mathrm{GH})$ releasing factor neurons in the rat arcuate nucleus following systemic injection of the GH secretagogue, GH-releasing peptite-6. Endocrinology 1997; 138:771-77.

43. Ahima RS, Antwi DA. Brain regulation of appetite and satiety. Endocrinol Metab Clin N Am 2008; 37:811-23.

44. Tschöp M, Smiley DL, Heiman ML. Ghrelin induces adiposity in rodents. Nature 2000; 407:908-913.

45. Seoane LM, López M, Tovar S, Casanueva FF, Señarís R, Diéguez C. Agouti-related peptite, neuropeptite $\mathrm{Y}$, and somatostatin-producing neurons are targets for ghrelin actions in the rat hypothalamus. Endocrinology 2003; 144:544-551.

46. Denis RG, Joly-Amado A, Webber E, Langlet F, Schaeffer M, Padilla SL, et al. Palatability can drive feeding independent of AgRP neurons. Cell Metab 2015; 22:646-57.

47. Pedrazzini T. Importance of NPY Y1 receptor-mediated pathways: assessment using NPY Y1 receptor knockouts. Neuropeptites 2004; 38:267-75.

48. Woods SC, Figlewicz DP, Madden L, Porte D, Sipols AJ, Seeley RJ. NPY and food intake: discrepancies in the model. Regul Pept 1998; (75-76):403-408.

49. Matsuda K, Kang KS, Sakashita A, Yahashi S, Vaudry H. Behavioral effect of neuropeptites related to feeding regulation in fish. Ann N Y Acad Sci 2011; 1220:11726.

50. Peng C, Chang JP, Yu KL, Wong AO, Van Goor F, Peter RE, et al. Neuropeptite-Y stimulates growth hormone and gonadotropin-II secretion in the goldfish pituitary: involvement of both presynaptic and pituitary cell actions. Endocrinology 1993; 132:1820-29.

51. Babaei S, Sáez A, Caballero-Solares A, Fernández F, Baanante IV, Metón I. Effect of dietary macronutrients on the expression of cholecystokinin, leptin, ghrelin and neuropeptite $Y$ in gilthead sea bream (Sparus aurata). Gen Comp Endocrinol 2017; 1(240):121-128. 
52. Hajimohammadi M, Shab-Bidar $S$, Neyestani TR. Consumption of vitamin D-fortified yogurt drink increased leptin and ghrelin levels but reduced leptin to ghrelin ratio in type 2 diabetes patients: a single blind randomized controlled trial. Eur J Nutr 2017. doi: 10.1007/s00394017-1397-z. [Epub ahead of print].

53. Parikh SJ, Edelman M, Uwaifo GI, Freedman RJ, Semega-Janneh $\mathrm{M}$, Reynolds $\mathrm{J}$, et al The relationship between obesity and serum 1, 25dihydroxy vitamin $D$ concentrations in healthy adults. J Clin Endocrinol Metab 2004; 89:1196-99.

54. Wortsman J, Matsuoka LY, Chen TC, Lu Z, Holick MF. Decreased bioavailability of vitamin D in obesity. Am J Clin Nutr 2000; 72:690-693.

55. Shab-Bidar S, Neyestani TR, Djazayery A, Eshraghian MR, Houshiarrad A, Gharavi $A$, et al. Regular consumption of vitamin D-fortified yogurt drink (doogh) improved endothelial biomarkers in subjects with type 2 diabetes: a randomized doubleblind clinical trial. BMC Med 2011; 9:125.

56. Shab-Bidar S, Neyestani TR, Djazayery A, Eshraghian MR, Houshiarrad A, Kalayi A, et al. Improvement of vitamin $D$ status resulted in amelioration of biomarkers of systemic inflammation in the subjects with type 2 diabetes. Diabetes Metab Res Rev 2012; 28:424-430.

57. van Dam RM, Hu FB, Rosenberg L, , Krishnan S, Palmer JR. Dietary calcium and magnesium, major food sources, and risk of type 2 diabetes in US black women. Diabetes Care 2006; 29:2238-2243.

58. Álvarez-Castro P, Pena L, Cordido F. Ghrelin in obesity, physiological and pharmacological considerations. Mini Rev Med Chem 2013; 13(4):541-52.

59. Goymann W, Lupib $S$, Kaiyad H, Cardinalee M, Fusanic L. Ghrelin affects stopover decisions and food intake in a long-distance migrant. PNAS 2017; 114 (8):1946-51.
60. Yu CH, Chu SC, Chen PN, Hsieh YS, Kuo DY. Participation of ghrelin signalling in the reciprocal regulation of hypothalamic NPY/POMC-mediated appetite control in amphetamine-treated rats. Appetite 2017; 113:30-40.

61. Chu SC, Chen PN, Hsieh YS, Yu CH, Lin $\mathrm{MH}$, Lin $\mathrm{YH}$, et al. Involvement of hypothalamic PI3K-STAT3 signalling in regulating appetite suppression mediated by amphetamine. British Journal of Pharmacology 2014; 171:3223-3233.

62. Wren AM, Small CJ, Abbott CR, Dhillo WS, Seal LJ, Cohen MA, et al. Ghrelin causes hyperphagia and obesity in rats. Diabetes 2001; 50(11):2540-7.

63. Druce MR, Wren AM, Park AJ, Milton JE, Patterson M, Frost G, Ghatei MA, Small C, Bloom SR. Ghrelin increases food intake in obese as well as lean subjects. Int J Obes (Lond) 2005; 29(9):1130-6.

64. Greenman Y, Golani N, Gilad S, Yaron M, Limor R, Stern N. Ghrelin secretion is modulated in a nutrient- and genderspecific manner. Clin Endocrinol (Oxf) 2004; 60(3):382-8.

65. Matsumura K, Tsuchihashi T, Fuji K, Abe I, lida M. Central ghrelin modulates sympathetic activity in conscious rabbits. Hypertension 2002; 40(5):694-9.

66. Choi K, Roh SG, Hong YH, Shrestha YB, Hishikawa D, Chen C, Kojima $\mathrm{M}$, Kangawa K, Sasaki S. The role of ghrelin and growth hormone secretagogues receptor on rat adipogenesis. Endocrinology 2003; 144(3):754-9.

67. Sominsky L, Ziko I, Nguyen TX, Andrews ZB, Spencer SJ. Early life disruption to the ghrelin system with over-eating is resolved in adulthood in male rats.

Neuropharmacology 2017; 113:21-30.

68. Hunschede S, Kubant R, Akilen R, Thomas S, Anderson GH. Decreased Appetite after High-Intensity Exercise Correlates with Increased Plasma Interleukin-6 in Normal-Weight and 
Overweight/Obese Boys. Curr Dev Nutr 2017; 1:1-10.

69. Raj DS, Moseley P, Dominic EA, Onime A, Tzamaloukas AH, Boyd A, Shah VO, Glew R, Wolfe R, Ferrando A. Interleukin6 modulates hepatic and muscle protein synthesis during hemodialysis. Kidney Int 2008; 73:1054-61.

70. De Jongh RF, Vissers KC, Booij LH, De Jongh KL, Vincken $P$, Meert TF. Interleukin-6 and perioperative thermoregulation and HPA-axis activation. Cytokine 2003; 21:248-56.

71. Wernstedt I, Edgley A, Berndtsson A, Faldt J, Bergstrom $\mathrm{G}$, Wallenius $\mathrm{V}$, et al. Reduced stress- and cold-induced increase in energy expenditure in interleukin-6-deficient mice. Am J Physiol Regul Integr Comp Physiol 2006; 291(3):551-7.

72. Wallenius V, Wallenius K, Ahren B, Rudling M, Carlsten H, Dickson SL, et al. Interleukin-6-deficient mice develop mature-onset obesity. Nat Med 2002; 8:75-9.

73. Bando $M$, Iwakura $H$, Ueda $Y$, Ariyasu $H$, Inaba $\mathrm{H}$, Furukawa $\mathrm{Y}$, et al. IL-1b directly suppress ghrelin mRNA expression in ghrelin-producing cells. Molecular and Cellular Endocrinology 2017; 447:45-51.

74. Schellekens H, Finger BC, Dinan TG, Cryan JF. Ghrelin signalling and obesity: At the interface of stress, mood and food reward. Pharmacology and Therapeutics 2012; 135:316-326.

75. Lutter M, Sakata I, Osborne-Lawrence S, Rovinsky SA, Anderson JG, Jung S, et al. The orexigenic hormone ghrelin defends against depressive symptoms of chronic stress. Nature Neuroscience 2008; 11:752-3.

76. Lu PH, Song YL, Hsu CH. Ghrelin level negatively predicts quality of life in obese women. Psychol Health Med 2017; 22(2):162-71.

77. Dickson SL, Egecioglu E, Landgren S, Skibicka KP, Engel JA, Jerlhag E. The role of the central ghrelin system in reward from food and chemical drugs. Mol. Cell. Endocrinol 2011; 340:80-87.

78. Skibicka KP, Hansson C, Egecioglu E, Dickson, S.L. Role of ghrelin in food reward: Impact of ghrelin on sucrose selfadministration and mesolimbic dopamine and acetylcholine receptor gene expression. Addict. Biol 2012; 17:95-107.

79. Diano S, Farr SA, Benoit SC, McNay EC, da Silva I, Horvath B, et al. Ghrelin controls hippocampal spine synapse density and memory performance. Nat Neurosci 2006; 9:381-88.

80. Kanoski SE, Fortin SM, Ricks KM, Grill $\mathrm{HJ}$. Ghrelin signaling in the ventral hippocampus stimulates learned and motivational aspects of feeding via PI3KAkt signaling. Biol Psychiatry 2013; 73:915-23.

81. Moon M, Kim HG, Hwang L, Seo JH, Kim $S$, Hwang $S$, et al. Neuroprotective effect of ghrelin in the 1-methyl-4-phenyl-1,2,3,6tetrahydropyridine mouse model of parkinson's disease by blocking microglial activation. Neurotox Res 2009; 15:332-47.

82. Frago LM, Chowen JA. Involvement of Astrocytes in Mediating the Central Effects of Ghrelin. Int J Mol Sci 2017; 2:18(3).

83. Sarmento-Cabral A, Peinado JR, Halliday LC, Malagon MM, Castaño JP, Kineman RD, et al. Adipokines (Leptin, Adiponectin, Resistin) Differentially Regulate All Hormonal Cell Types in Primary Anterior Pituitary Cell Cultures from Two Primate Species. Nature 2017; 7:43537.

84. Sinha MK, Ohannesian JP, Heiman ML, Kriauciunas A, Stephens TW, Magosin S, et al. "Nocturnal rise of leptin in lean, obese, and non-insulindependent diabetes mellitus subjects," The Journal of Clinical Investigation 1996; 97(5):1344-1347.

85. Licinio J, Mantzoros C, Negr̃ao AB, Cizza $\mathrm{G}$, Wong ML, Bongiorno PB, et al. "Human leptin levels are pulsatile and inversely related to pituitary-adrenal function," Nature Medicine 1997; 3(5):5759, 
86. Friedman JM, Halaas JL. Leptin and the regulation of body weight in mammals. Nature 1998; 395:763-70.

87. Banks WA, Kastin AJ, Huang W, Jaspan JB, Maness LM. Leptin enters the brain by a saturable system independent of insulin. Peptites 1996; 17:305-11.

88. Bouret SG, Draper SJ, Simerly RB. Formation of projection pathways from the arcuate nucleus of the hypothalamus to hypothalamic regions implicated in the neural control of feeding behavior in mice. J Neurosci 2004a; 24:2797-805.

89. Yura S, Itoh H, Sagawa N, Yamamoto $H$, Masuzaki H, Nakao K, et al. Role of premature leptin surge in obesity resulting from intrauterine undernutrition. Cell Metab 2005; 1:371-378.

90. Bouret SG, Draper SJ, Simerly RB. Trophic action of leptin on hypothalamic neurons that regulate feeding. Science 2004b; 304:108-10.

91. Zhang Y, Proenca R, Maffei M, Barone $M$, Leopold L, Friedman JM. Positional cloning of the mouse obese gene and its human homologue. Nature 1994; 372(6505):425-32.

92. Weigle DS, Bukowski TR, Foster DC, Holderman S, Kramer JM, Lasser $\mathrm{G}$, et al. Recombinant ob protein reduces feeding and body weight in the ob/ob mouse. J Clin Invest 1995; 96(4):2065-70.

93. Farooqi IS, Matarese G, Lord GM, Keogh JM, Lawrence E, Agwu C, et al. Beneficial effects of leptin on obesity, T cell hyporesponsiveness, and neuroendocrine/metabolic dysfunction of human congenital leptin deficiency. J Clin Invest 2002; 110(8):1093-103.

94. Sinha MK, Caro JF. Clinical aspects of leptin. Vitam Horm 1998; 54:1-30.

95. Kastin AJ, Pan W. Dynamic regulation of leptin entry into brain by the blood-brain barrier. Regul Pept 2000; 92(1-3):37-43.

96. Elias CF, Aschkenasi C, Lee C, Kelly J, Ahima RS, Bjorbaek C, et al. Leptin differentially regulates NPY and POMC neurons projecting to the lateral hypothalamic area. Neuron 1999; 23(4):775-86

97. van den Top $M$, Lee $K$, Whyment $A D$, Blanks AM, Spanswick D. "Orexigensensitive NPY/AgRP pacemaker neurons in the hypothalamic arcuate nucleus," Nature Neuroscience 2004; 7(5):493-494.

98. Farooqi IS, Wangensteen $T$, Collins $S$, Kimber W, Matarese G, Keoghet JM, et al. Clinical and molecular genetic spectrum of congenital deficiency of the leptin receptor. The New England Journal of Medicine 2007; 356(3):237-47.

99. Garcia-Caceres C, Fuente-Martin E, Burgos-Ramos E, Granado M, Frago LM, Barrios $V$ et al. Differential acute and chronic effects of leptin on hypothalamic astrocyte morphology and synaptic protein levels. Endocrinology 2011; 152:1809-18.

100. Pan W, Hsuchou H, Xu C, Wu X, Bouret SG, Kastin AJ. Astrocytes modulate distribution and neuronal signaling of leptin in the hypothalamus of obese A vy mice. J Mol Neurosci 2011; 43:478-84.

101. Martin R, Cordova C, Gutiérrez $B$, Hernández $M$, Nieto $M L$. A dangerous liaison: Leptin and SPLA2-IIA join forces to induce proliferation and migration of astrocytoma cells. PLoS One 2017; 12(3):0170675.

102. Garcia-Caceres C, Yi CX, Tschop $\mathrm{MH}$. Hypothalamic astrocytes in obesity. Endocrinol Metab Clin North Am 2013; 42:57-66.

103. Thaler JP, Yi CX, Schur EA, Guyenet SJ, Hwang BH, Dietrich MO et al. Obesity is associated with hypothalamic injury in rodents and humans. J Clin Invest 2012; 122:153-162.

104. Hsuchou H, He Y, Kastin AJ, Tu $\mathrm{H}$, Markadakis EN, Rogers RC, et al. Obesity induces functional astrocytic leptin receptors in hypothalamus. Brain 2009; 132(4): 889-902.

105. Steculorum SM, Vogt MC, Bruning JC. Perinatal programming of metabolic diseases:role of insulin in the development 
of hypothalamic neurocircuits. Endocrinol

Metab Clin North Am 2013; 42:149-164.

106. Ferezou-Viala J, Roy AF,

Serougne C, Gripois D, Parquet M,

Bailleux $V$ et al. Longterm consequences

of maternal high-fat feeding on

hypothalamic leptin sensitivity and dietinduced obesity in the offspring. Am J

Physiol Regul Integr Comp Physiol 2007; 293: R1056-R1062.

107. Logan CA, Bornemann R, Koenig W, Reister F, Walter V, Fantuzzi G, et al. Gestational Weight Gain and FetalMaternal Adiponectin, Leptin, and CRP: results of two birth cohorts studies. Sci Rep 2017; 2(7):41847.

108. Desai M, Li T, Ross MG. Fetal hypothalamic neuroprogenitor cell culture: preferential differentiation paths induced by leptin and insulin. Endocrinology 2011; 152: 3192-201.

109. Bouret SG. Early life origins of obesity: role of hypothalamic programming. J Pediatr Gastroenterol Nutr 2009; 48(1):31-8.

110. Ainge $\mathrm{H}$, Thompson $\mathrm{C}$, Ozanne SE, Rooney KB. A systematic review on animal models of maternal high fat feeding and offspring glycaemic control. Int J Obes (Lond) 2011; 35:325-35.

111. Sullivan EL, Grove KL. Metabolic Imprinting in Obesity. Forum Nutr 2010; 63:186-194.

112. Kjaergaard M, Nilsson C, Secher A, Kildegaard J, Skovgaard T, Nielsen $\mathrm{MO}$, et al. Differential hypothalamic leptin sensitivity in obese rat offspring exposed to maternal and postnatal intake of chocolate and soft drink. Nutrition \& Diabetes 2017; 7:242.

113. Yeo GS, Heisler LK. Unraveling the brain regulation of appetite: lessons from genetics. Nat Neurosci 2012; 15(10):1343-9. 